\section{A hero's fight}

\section{Barbara J. Culliton}

Beyond Love. By Dominique Lapierre. UK Century/US Warner: 1991. Pp.464. $£ 15 / \$ 22.95$.

BEYOND Love is the only book I have read that carries a dust-jacket endorsement from the Pope. John Paul II called it "a remarkable testimony of human solidarity".

And indeed it is. This is on one level a simple, even pat, tale of heroes who fight disease and, when defeated, bravely face death. Written by popular French author Dominique Lapierre, Beyond Love weaves the story of the AIDS epidemic with the saga of a young Indian untouchable who literally emerges from the river Ganges, where her low-caste family oversees the burial of the dead, to become a shining light in Mother Teresa's Palace of the Immaculate Heart where her nuns ministered to the dying poor.

Lapierre, who spends a good deal of his time in India, also spent time interviewing American and French AIDS researchers for his account of AIDS, which begins dramatically in room 516 of the hospital at the University of California at Los Angeles. Here, a freelance homosexual model with bizarre symptoms is seen by Michael Gottlieb, a dedicated young immunologist with "a fertile mind" who leaves no book unread in his effort to figure out why his 31 year-old patient has lost his immune system. It was Gottlieb, not much mentioned any longer in the AIDS drama, who saw the world's first diagnosed AIDS patients in 1980 . through medical circles as physicians in New York and elsewhere discovered that they all had as patients young homosexual men who were dying of a strange immune disorder. From there it is a quick leap to the Centers for Disease Control in Atlanta where in 1981 a "commando of very special supercops" headed by James Curran faces the fact that a new disease of potential epidemic proportions has been unleashed on the world.

No tale of AIDS would be complete without Robert C. Gallo of the US National Cancer Institute and Luc Montagnier of the Institut Pasteur in Paris, and Lapierre does not disappoint us. Lapierre takes the French view of argued events, casting Gallo as Goliath and Montagnier as David. By setting the most dramatic research scenes of his soap opera at the Pasteur, he portrays Montagnier, his former colleague Jean ClaudeChermann and Francoise Barre-Sinoussi as
Lapierre traces the course of AIDS

the basic scientist heroes of the AIDS campaign. In keeping with the stereotypical character of the book, Lapierre falls into the trap of describing the men in terms of experiences that affected their lives as scientists while expressing implicit amazement that a woman can be a woman and a researcher at the same time. Thus, we learn that Barre-Sinoussi was "just as capable of rustling up a traditional blanquette of veal or a Grand Marnier souffle as she was of lovingly cultivating her fragile lymphocytes." How about that.

A sophisticated reader will find Lapierre's language and style that of a grade- $\mathrm{B}$ novel. Biologists coming to this book will find errors. It is not a prize-worthy piece of writing.

Nevertheless, Beyond Love is in its way a

IMAGE
UNAVAILABLE
FOR COPYRIGHT
REASONS

NATURE · VOL $351 \cdot 16$ MAY 1991 reached his salivary glands, burning his tongue and throat with a burst of fire no blow. The lesions of Kaposi's sarcoma liquid could quench." Stein survived a few days until the violet Kaposi's pustules "blocked the entrance to the esophagus altogether," and he died gasping for air.

It is not pleasant reading, but it is part of the real story of AIDS and is something Lapierre rightly includes. This is a book that is hard to classify, being at once simplistic, even trite in language and structure, and yet nonetheless moving overall. If one forgets the details and focuses only on the general impression a lay reader will get from this book, Beyond Love does an interesting job of informing the public about some of the realities of science and medicine.

Barbara J. Culliton is Deputy Editor of Nature.

\section{Sketches of science}

\author{
James C. G. Walker
}

Chemical Evolution: Origin of the Elements, Molecules and Living Systems. By Stephen F. Mason. Oxford University Press. 1991. Pp.317. £19.50.

Among the presents described by Dylan Thomas in A Child's Christmas in Wales were "books that told me everything about the wasp, except why". Chemical Evolution by Stephen F. Mason is one of those books, not about the wasp of course, but about the origin and evolution of nearly everything.

The idea of telling in one book the story of the origin of the elements, stars, galaxies, planets and life is not new. Much the same ground was covered by Wallace $\mathrm{S}$. Broecker in How to Build a Habitable Planet (Eldigio, 1985). What is new here is the combination of the history of matter in the Universe with the history of the scientific study of this matter. Together, these add up to a lot of history. The subjects are all here, from 'absolute magnitude' to 'zinc', 'zircon' and 'zymase'. So are the people, from Adams, W. S. (1876-1956) to Zeeman, P. (1865-1943). Apart from Hipparchus of Rhodes (c.170c.125 BC), whose observation of a solar eclipse in 129 BC has been used to measure the lengthening of the day, the oldest birth dates in the index are those of W. Gilbert (1544-1603), T. Brahe (1546-1601), J. Kepler (1571-1630) and J. B. van Helmont (c.1579-1644). Gilbert studied terrestrial magnetism at the court of Queen Elizabeth, and van Helmont worked in Brussels on the transmutation of elements. The most recent birth date seems to be that of R. W. Wilson (1936), who discovered, with A. A. Penzias (1933), the cosmic microwave background radiation.

Regrettably, it is more fun to dip into the index for small facts about scientific notables than it is actually to read the book. The author describes his work as being in the 